\title{
Emerging issues in the Mexican legislation on the use of personal data in medical care and confidentiality as a right of physicians
}

\author{
César Francisco Contreras-López \\ Universidad Autónoma de Baja California, Faculty of Medicine, Mexicali, Baja California, Mexico
}

\begin{abstract}
Recently, new laws on the handling of personal data have been published. Physicians should know them, since the information they obtain from the patient has been subject to what is therein established. To harmonize medical activity with these provisions, it is necessary to review the current legal framework. After this analysis, we observed that data the doctor registers in the medical record in the form of opinions or technical observations directed to other health professionals are not included. We consider this information should be protected the same way as that of the patient, in order to give legal certainty to the right of doctors to the discretion and confidentiality established in the "prescriptive freedom".
\end{abstract}

KEY WORDS: Personal data. Legal framework. Information protection.

\section{Background}

Secrecy in the handling of information obtained by the physician during the development of the medical act presupposes the obligation to maintain certain data and at certain circumstances under good protection, preventing that its disclosure might cause any harm to the personal, social, religious, etc. integrity of the patient.

The above principle is not new to the doctor. From a deontological point of view, there are documents such as the Hippocratic Oath, Asclepius Advice and the International Code of Medical Ethics where the obligation to keep information entrusted by patients under absolute secrecy as a basic ethical principle in the exercise of the profession.

With regard to legal regulations, since last century, the Criminal Code contains the crime of "disclosure of secrets" that forces confidentiality in the management of information, especially when the responsibility of secrecy is acquired as a professional or public servant (articles 210 and 211 of the Federal Criminal Code in force). In turn, Constitutional Article 5 Regulatory Law on the practice of professions in the
Federal District, imposes on the professional the obligation to "strictly keep the secrecy of matters conferred to him/her by his/her clients" (article 36). Similar provisions were found in the NOM 168 standard for the medical record (section 5.6) and in the NOM 190 standard on criteria for the medical care of intrafamily violence (section 5.7), recently replaced by NOM-004 and NOM 046, respectively.

As part of the second reform that was applied to article 6 of our Constitution in 2007, a clearer meaning is given to the "right of access to information", laying the groundwork for the full exercise of this guarantee and forcing the State to clearly and opportunely make the information in possession of any entity of the government available to any citizen. However, when it comes to information resulting from medical care, protection continues in the use it is given because it is considered part of people's private life (currently, article 6, section A, fraction II of the Political Constitution).

Protection, access, rectification and cancellation of the use of personal data acquired the nature of fundamental human right when Article 16 of the Constitution was modified in 2009.
Gac Med Mex. 2018;154:593-597

Contents available at PubMed www.gacetamedicademexico.com 


\section{Definition of concepts}

It is necessary for certain definitions to be remembered in order to place the context when talking about protection of the information entrusted by the patient and that which the doctor produces during medical care.

By personal data, any information concerning an identified or identifiable natural person is to be understood (article 3, section V of the Federal Law for the Protection of Personal Data in Possession of Individuals); this definition includes the name, surname, address, e-mail and also those data that have a greater relationship with the privacy of their holder. ${ }^{1}$

Sensitive personal data is to be understood as: ${ }^{2}$

Those personal data that affect the most intimate sphere of their holder, or whose improper use may give rise to discrimination or entails a serious risk for him/her. In particular, those that may reveal aspects such as racial or ethnic origin, present and future health status, genetic information, religious, philosophical and moral beliefs, union affiliation, political opinions or sexual preference are considered to be sensitive.

Physician's prescriptive freedom is a scientific and ethical principle that aims at guiding the practice of the medical profession, granting professionals, technicians and their assistants of the health disciplines discretion in their actions. Prescriptive freedom should be exercised aiming to obtain the benefit of the patient and under no circumstances should it be equated to arbitrariness, since medical personnel actions must be based on medical science current state and be directed at every moment to the benefit of the patient, taking into consideration the circumstances of each case. $^{3}$

Confidentiality consists in keeping secret the information that affects individuals' private life. Everyone has the right for the confidential nature of the data referring to their health to be respected, since nobody can access them without prior authorization under the protection of the law. ${ }^{4}$

\section{Legal provisions for the management of personal data applicable to health personnel}

\section{Political Constitution of the Mexican United States}

The right to information was integrated to article 6 of our Constitution in $1977 .{ }^{5}$ Subsequently, in July 2007, the principles and bases for the exercise of the access to information right were added to this article as section A with seven fractions, out of which we are especially interested in fraction II, which reads: "the information that refers to private life and personal data will be protected in the terms and with the exceptions established by the law." 6 Both these precedents can be considered as the most decided step in Mexico towards the quest for the right to maintain personal information private. At the constitutional level, the next step was taken in 2009 when the following was added to article 16: "Every individual has the right to the protection of his/her personal data, to access, rectification and cancellation thereof, as well as to express his/her opposition..."

\section{Law on Transparency and Access to Government Public Information}

In this first specific law, published in 2002, every individual was granted access to information in possession of the Powers of the Union, autonomous constitutional or legally autonomous bodies and of any other federal entity. This law was invalidated and replaced in 2016.

\section{Federal Law for the Protection of Personal Data in Possession of Individuals}

Published as a new law on July 5, 2010, its purpose is:

The protection of personal data in possession of individuals, with the purpose to regulate their legitimate, controlled and informed handling, in order to guarantee the privacy and the right to informative self-determination of people.

As the name implies, it is applicable when the use of personal data is made by individuals. In the provision of health services, it is applied in those who carry out activities in the private sphere in places such as general or specialty medicine offices, clinics, hospitals, laboratories, pharmacies, etc. Among the most important concepts to be highlighted in this law we can mention the following:

- The acquisition of personal data should not be made through deception or fraud.

- The handling of personal data will be subject to the holder's consent (the natural person to whom the personal data correspond), which will be express when done verbally, in writing, by electronic means, etc., or tacit when the holder does not express opposition when shown the privacy notice. 
- When it comes to sensitive personal data, the person responsible (the person who decides on the handling of personal data) must obtain express written consent of the holder through autograph or electronic signature.

- Sensitive personal data do not require the above consent when they are indispensable for medical care, prevention, diagnosis, medical treatments, among others.

- If the person responsible plans to use the data for a different purpose that has not been established in the privacy notice, he/she will have to obtain consent of the holder.

- The privacy notice is the printed, digital, visual, audio, etc. document where the responsible person informs the holder on the purposes the information is collected for. In case of sensitive data, the fact that it is this type of data should be expressed.

- The holder has the right to request access, rectification, cancellation and opposition with regard to his/her personal data (ARCO rights).

\section{General Law on Transparency and Access to Public Information}

Published on May 4, 2015, this law replaces The Federal Law of Transparency and Access to Public Government Information (2002). This is constitutional Article 6 regulatory law. It establishes the principles, general bases and procedures to guarantee the right to access to information in possession of regulated entities at any government entity that receives and uses public resources or performs acts of authority of the federation, the states and the municipalities. It refers to access to information as a human right.

\section{Federal Law on Transparency and Access to Public Information}

Published on May 9, 2016, its purpose is to provide the necessary means at the federal level in order to guarantee the right to have access to public information in possession of any government entity that receives and uses public resources or performs acts of authority of the federation. According to this law, confidential information is "... that which contains personal data relating to an identified or identifiable natural person..." and may only be accessed by the holders thereof, their representatives and public servants thereto entitled.

\section{General Law for the Protection of Personal Data in Possession of Regulated Entities}

In turn, this law regulates section A of article 6 and second paragraph of article 16 , both of our constitution, for the protection of personal data in possession of regulated entities, i.e., it applies to people who perform their activities in the field of medicine as government employees. This is the most recent law in this matter, since it was published for the first time in January 2017. Among its main provisions, the following stand out:

- The person responsible will not be obliged to obtain consent of the holder for the handling of his/her personal data when personal data are required in order to exercise a right or fulfill obligations deriving from a legal relationship between the holder and the responsible party (such as the medical act is).

- The same applies when there is a situation of emergency that potentially can harm an individual on his/her person and when his/her data are necessary to carry out a treatment for prevention, diagnosis and healthcare provision.

- To request the ARCO rights at any time. This exercise should be carried through an application where the holder's identity is confirmed. In the case of minors, a different person or deceased individuals, the interested party must prove the identity and personality whereby he/she acts.

\section{Constitutional Article 5 Regulatory Law, on the Practice of Professions in the Federal District}

On this subject, this law, in article 36 refers that "every professional will be obliged to strictly keep the secrecy of matters to him/her entrusted by his/her customers..."

\section{Regulation of the General Statute of Health in Matters of Medical Care Service Provision}

Derived from the General Statute of Health, the regulations in matters of medical care establish in article 29 that "every health professional shall be obliged to provide the user, family member, legal guardian or representative, complete information about the corresponding diagnosis, prognosis and 
treatment". In addition, it forces the responsible health professional to "provide a clinical summary about the diagnosis, evolution, treatment and prognosis of the condition that warranted admission" (article 30).

\section{Official Mexican Standard NOM-004- SSA3-2012, on the medical record}

This standard is the one that confirms the ownership, right holder nature and confidentiality criteria (among others) for the handling of information and specifically of the medical record.

In its introduction, the standard indicates the recognition of the patient's ownership of the data that he/she provides to personnel of the health area (information that will be registered in the corresponding notes), which are considered confidential and that the health personnel, in compliance with the ethical principles that govern their profession, must keep secret.

Also, in what seems an attempt to provide security to health personnel about the notes they make, protection is provided to personal data, and they are granted confidentiality; however, it is not clearly established whether this refers to health personnel personal data or if it continues referring to patients' personal data.

As regards medical record ownership, it is clearly stated that it belongs to the service provider (5.4). This provision can generate a conflict between doctor and patient, since it should be clearer than the right of the latter is restricted only to have access to the information contained within the medical record, not to exercise rights on the medical record itself.

\section{Obligation to disclose medical secrets or personal data}

There are also legal ordinances that in certain circumstances force the doctor to disclose personal data or other information about patient care in order to prevent health risks or during procedures carried out by judicial or administrative authorities.

\section{General Statute of Health}

This law is applicable in the cases established by the above laws in relation to the handling of personal data in possession of regulated entities and individuals, when the health service provider (public or private) considers it necessary for said information to be disseminated for the purposes of prevention and control of diseases and accidents, as established in chapter II of the eighth title of this law regarding communicable diseases, since Article 136 mentions that notification to the Ministry of Health is mandatory for diseases such as yellow fever, plague and cholera, which must immediately notified, as well as those that occur in the form of an outbreak or epidemic and in a term no longer than 24 hours such as poliomyelitis, meningococcal meningitis, viral influenza, measles, malaria, immunodeficiency virus infection, among others.

\section{Official Mexican Standard NOM-004- SSA3-2012, on the medical record}

The standard establishes that personal data can only be provided to third parties upon the patient's written request (5.5.1); this can be done verbally or in writing in the form of a clinical summary, as long as it is, in turn, requested in writing. When thus requested by a judicial authority, law enforcement bodies and administrative authorities, the medical record must be handed over (5.6).

Special mention deserves the authorization granted by this same regulation when the disclosure of personal data is for teaching and research purposes, in which case patient written consent must be obtained and the necessary measures should be adopted in order for him/her not to be able to be identified.

\section{Official Mexican Standard NOM-046- SSA2-2005, family, sexual violence and violence against women, criteria for prevention and care}

This regulation forces medical service providers who treat patients in this situation to inform the public prosecutor for "the purposes of relevant enforcement of justice" (5.10) and each case should be notified to the Ministry of Health for the corresponding epidemiological surveillance (5.11).

\section{National Code of Penal Procedures}

In this new code, published in 2014, article 362 establishes that the testimony of doctors, psychologists, nurses (among other professionals and public servants) is inadmissible owing to their duty to keep the 
confidentiality of information that is not susceptible of disclosure according to applicable laws, unless the interested party releases them from the responsibility of that duty.

\section{Conclusions}

After analyzing the new federal provisions for the handling of personal data, as well as those already existing, we observe that in none of them has the position of health professionals and technicians been taken into account with regard to the notes that, as part of their work, they write down in the medical record.

In 2012, Davara Fernández already mentioned the need to develop a specific regulatory framework where intellectual property of the comments and opinions of the health professional are protected; ${ }^{7}$ howev$\mathrm{er}$, in the present review of the legal framework, we only found a slight approach to this in NOM-004.

Access to the medical record remains beyond the control of health personnel despite its ownership thereof being recognized, since the patient (or the persons he/she designates), as well as authorities, can get the information at any time and for the purposes that they consider pertinent.

Notes that in the form of observations, appreciations, comments or opinions are made by health personnel with regard to medical care are, largely, of a subjective nature and therefore responsibility of each person, and thus we consider it necessary for information legal confidentiality to be extended to protect health personnel from interference and inappropriate use of certain notes, in order to this way guarantee the right of the physician to prescriptive freedom as a medical practice guiding principle, keeping under legal guardianship the information written down by health personnel in the medical record, without derogation of the right of the patient to access his/her information, which is granted by the new laws on the subject.

\section{References}

1. Cano GA. Protección de datos personales en el marco del derecho a la salud y el valor de la confidencialidad en la relación médico-paciente. Mesa de discusión. Memoria Simposio Conamed. 2016;4(4): 237-244.

2. Ley Federal de Protección de Datos Personales en Posesión de los Particulares, artículo 3, fracción VI. Diario Oficial de la Federación 2010 Jul 5.

3. Libertad prescriptiva del médico. Parte integradora del derecho al trabajo de los médicos. Tesis aislada 1a XXII/2013 (10a), primera sala. Décima época. Semanario Judicial de la Federación y su Gaceta, libro XVI, enero de 2013. p. 637. Disponible en: https://sjf.scjn.gob.mx/sjfsist/Documentos/Tesis/2002/2002564.pdf

4. Frigieri AJ. Las historias clínicas. Aspectos jurídicos y el derecho a la reserva de la información. Revista CONAMED. 2014;9(4):19-25.

5. Decreto que reforma y adiciona los artículos $6,41,51,52,53,54,55,60,61$, $65,70,73,74,76,93,97$ y 115 de la Constitución Política de los Estados Unidos Mexicanos. Diario Oficial de la Federación 1977 Dic 6. Disponible en: http://www.dof.gob.mx/nota_detalle.php?codigo=4664439\&fecha=06/12/1977

6. Decreto por el que se adiciona un segundo párrafo con siete fracciones al Artículo 6o. de la Constitución Política de los Estados Unidos Mexicanos. Diario Oficial de la Federación 2207 Jul 20. Disponible en: http://www. dof.gob.mx/nota_detalle.php?codigo=4994148\&fecha=20/07/2007

7. Fernández ID. Breve aproximación a las implicaciones jurídicas y operativas del tratamiento de datos de salud. Gaceta Médica de México. 2012; 148:480-6. 